\title{
Farmers' Participatory Site Specific Nutrient Management in Gangetic Tidal Floodplain Soil for High Yielding Boro Rice (Oryza Sativa L.)
}

\author{
D. K. Nath ${ }^{1 *}$, F. Haque ${ }^{1}$, F. Amin ${ }^{1}$, M. Sh. Islam ${ }^{1}$ and M. A. Saleque ${ }^{2}$ \\ ${ }^{I}$ CSISA-IRRI Project, International Rice Research Institute (IRRI), Barisal-8200, Bangladesh \\ ${ }^{2}$ CSISA-IRRI Project, International Rice Research Institute (IRRI), Dhaka-1213, Bangladesh \\ *Corresponding author and Email: dknath2004@ gmail.com
}

Received: 12 December $2012 \quad$ Accepted: 18 May 2013

\begin{abstract}
Site Specific Nutrient Management (SSNM) trials were conducted for irrigated, transplanted and high yielding rice (Oryza sativa L.) during Boro season 2012. Four treatments (NPK, PK, NK, and NP) were applied in a randomized complete block design to assess the effects of indigenous nutrient elements on rice yield and yield components. The trials were conducted so as to develop a site specific nutrient management approach for the farmers of Gangtic Tidal Floodplain ecosystem. The highest grain-yield of $5.64 \mathrm{t} \mathrm{ha}^{-1}$ was observed in NPK treatment, which gave 9.0, 34.4 and $50.7 \%$ higher yields than those of NP, NK and PK, respectively. The response to indigenous $\mathrm{K}$ was remarkable and it gave the second highest yield $\left(5.13 \mathrm{t} \mathrm{ha}^{-1}\right)$. The yield response to indigenous $\mathrm{N}$ was very poor and the lowest yield was found in $\mathrm{N}$ omission treatment $\left(2.78 \mathrm{t} \mathrm{ha}^{-1}\right)$. The response to indigenous $\mathrm{P}$ was also poor $\left(3.7 \mathrm{tha}^{-1}\right)$. This result shows that nitrogen and phosphorus are the most vibrant factors to increase yield since omission of $\mathrm{N}$ and $\mathrm{P}$ had significant impact on yield during Boro season. Use of $\mathrm{N}, \mathrm{P}$ and $\mathrm{K}$ at $128.7,8.08$ and $12.78 \mathrm{~kg}$, respectively could be recommended for growing BRRI dhan47 in Boro season. It could save P and K nutrient by 55.11 and $75.89 \%$ compared to that of NPK treatment, respectively.
\end{abstract}

\section{Keywords: Grain-yield, Nutrient omission, Rice, Site specific nutrient dose}

\section{Introduction}

Bangladesh is an agricultural country but still it does not have site specific nutrient management guideline. Fertilizer recommendation guide is available for 30 agro-ecological zones with little differentiation for different crop-seasons (BARC, 2005). On the other hand, because of limited access to soil-testing services and small land parcels (0.1-0.3 ha), fertilizer recommendations based on soil-test results are not yet practical in the farmers' fields. For modern rice cultivation, Bangladesh Rice Research Institute (BRRI) has given a fertilizer recommendation guide but it is a too general guideline for Bangladesh (BRRI,
2011). Soil fertility, fertilizer use and crop response to fertilizer may vary among rice fields within smaller irrigated and rain-fed environments (Cassman et al., 1999). We have national soil map but it is difficult to recognize soil fertility difference within a village of 150 ha by the national soil map.

Farmers do not apply uniform fertilizers in all plots of a national map unit due to different productivity level, but they desire uniform yields from all plots. The national soil map cannot acknowledge this productivity variation with such small area of a village. However, farmers have their own perception about soil-fertility and 
they change it constantly, taking into consideration the factors that favor crop performance, such as plot size, location, previous fertilizer use, weed infestation and pest build-up (Saleque et al., 2008). With trial and error and experience, farmers generally know which area of a field is more productive than the others and accordingly, they assess nutrient needs for different parts of a field (Saleque et al., 2005). Farmers' experience on village level soil fertility gradients generally agree well with the soil test results (Saleque et al., 2005 and Maniruzzaman et al., 2008). However, in most cases, they use excess and imbalanced fertilizer does. As a result, soil fertility as well as soil quality are degrading significantly day by day. On the other hand, sustainable farming systems require soil fertility status to be maintained at a level that supports satisfactory plant growth while minimizing nutrient loss to the environment (Betteridge et al., 2008). The use of site-specific nutrient management tool has been shown to be a simple and effective way to increase nitrogen use efficiency (Khosla et al., 2002).

Site specific nutrient management (SSNM) has the potential to increase fertilizer use efficiency as well as grain yield in the farmers' fields (Khurana et al., 2007) and is also an important way to minimize soil fertility degradation. Plant nutrients such as $\mathrm{N}, \mathrm{P}$ and $\mathrm{K}$ are often applied to plants to ensure economically viable grain yields in large-scale cropping systems (Swanson, 1982). The condition of 2 soils of Gangetic tidal floodplain was the "best", having high mineral, non-exchangeable and available $\mathrm{K}$, high release potential and medium fixation rate (Moslehuddin and Egashira, 1999). As soil native fertility may effectively be determined by the nutrient omission plot technique (Chowdhury et al., 2007 and Amina et al., 2010), K use efficiency can be increased by SSNM. A study (Khurana et al., 2007) showed that site specific nutrient management led to an increase in gross return over fertilizer (GRF) by $\$ 79.3$ ha $^{-1} \operatorname{crop}^{-1}(14 \%)$.

The present study with the nutrient omission plot was undertaken to assess the effects of indigenous nutrient elements (especially $\mathrm{N}, \mathrm{P}, \mathrm{K}$ ) on rice yield and yield components during Boro season at Nilganj union of Patuakhali district in order to develop a site specific nutrient management approach for farmers for increased fertilizer use efficiency.

\section{Materials and Methods}

On-farm participatory Site Specific Nutrient Management (SSNM) experiment was conducted with 5 farmers of Nilganj union $\left(27^{\circ} 56^{\prime} \mathrm{N}\right.$ latitude and $090^{\circ} 11^{\prime}$ E longitude) in Kalapara Upazila of Patuakhali district during the Boro season 2012. The site belongs to the Gangetic Tidal Floodplain soil of Agro-ecological Zone (AEZ) 13. This is the south-central coastal part of Bangladesh. The most common cropping system is rice-fallow-fallow due to soil and water salinity. The farms were typically clustered into 3 villages and selected from farmers of similar socio-economic conditions. Soil types and farm management practices were also common. Four fertilizer treatments: balanced fertilizer (NPK), nitrogen omission (PK), phosphorus omission (NK), and potassium omission (NP) were applied in the trial. Blanket doses of other nutrients were applied to all treatments to prevent deficiencies other than nitrogen $(\mathrm{N})$, phosphorus $(\mathrm{P})$, or potassium $(\mathrm{K})$. This included Zinc $(\mathrm{Zn})$ and sulfur $(\mathrm{S})$. In the trial $\mathrm{N}, \mathrm{P}, \mathrm{K}, \mathrm{S}$ and $\mathrm{Zn}$ were used at 125.3, 18, 53, 13.67 and $2.73 \mathrm{~kg}$ per hectare in the form of Urea, Triple Super Phosphate (TSP), Muriate of Potash (MoP), Gypsum and Zinc Sulfate (272, 90, 106, 76 and $7.6 \mathrm{~kg}$ per hectare, respectively) (BRRI 2011). TSP, MoP, Gypsum, and Zinc Sulfate were given as basal does and Urea was topdressed three times.

Salt tolerant rice-variety BRRI dhan47 was chosen by all the farmers. For irrigation, surface water was used from Pakhimara canal where there was a sluice gate to protect saline water entrance from the river. Though the water salinity of adjacent river went up to $32 \mathrm{dS} \mathrm{m}$, canal water salinity ranged between 2.35 to 4.6 $\mathrm{dS} \mathrm{m} \mathrm{m}^{-1}$ (Fig. 1). 


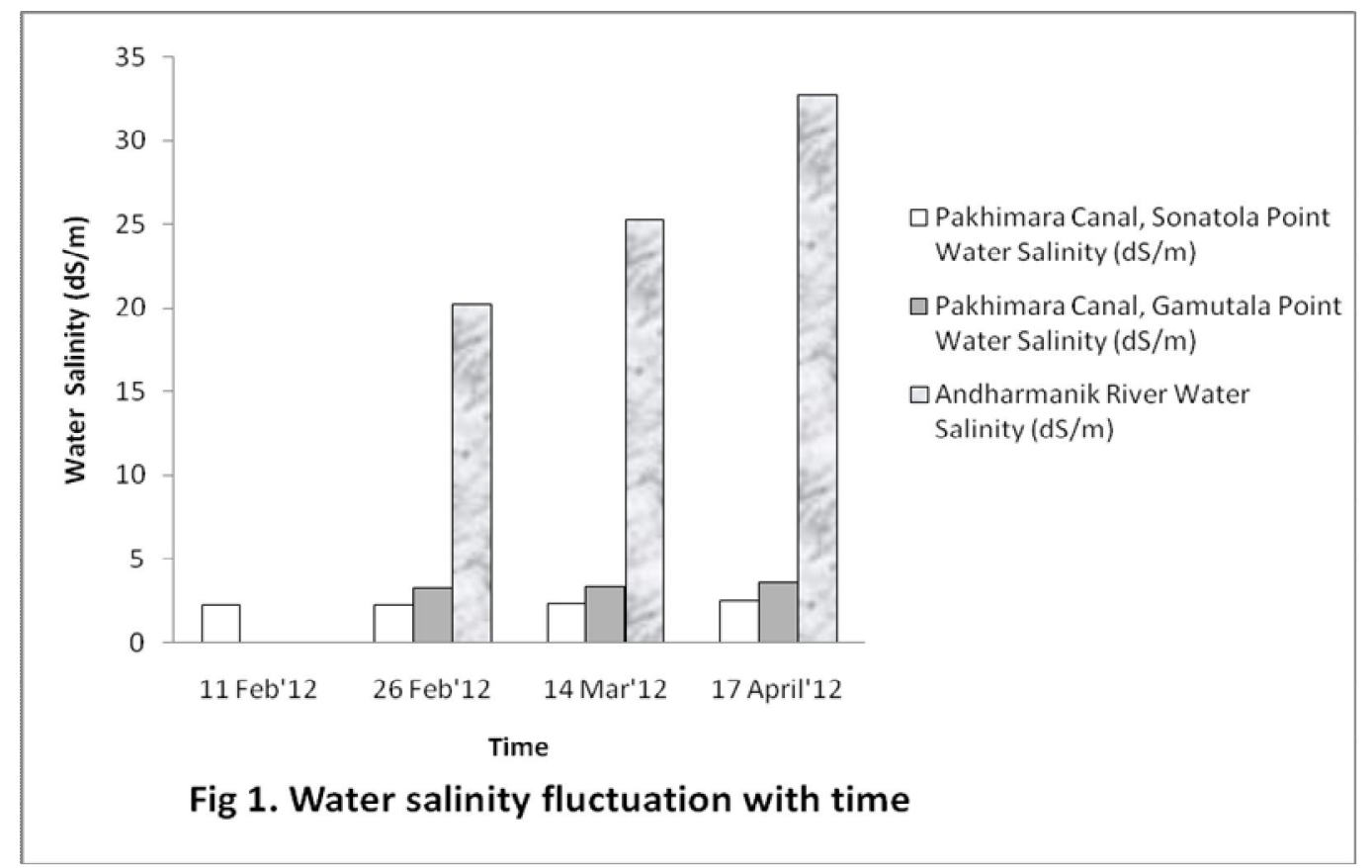

Table 1. Date of sowing, transplanting and harvesting for SSNM Trial plots, Kalapara, Boro, 2012

\begin{tabular}{clcc}
\hline Replication & Date of Sowing & $\begin{array}{c}\text { Date of } \\
\text { transplanting }\end{array}$ & $\begin{array}{c}\text { Date of } \\
\text { Harvesting }\end{array}$ \\
\hline 1 & 22 December, 2011 & 22 January, 2012 & 28 April, 2012 \\
2 & 25 December, 2011 & 27 January, 2012 & 30 April, 2012 \\
3 & 25 December, 2011 & 25 January, 2012 & 25 April, 2012 \\
4 & 18 December, 2011 & 25 January, 2012 & 03 May, 2012 \\
5 & 27 December, 2o11 & 23 January, 2012 & 03 May, 2012 \\
\hline
\end{tabular}

Water salinity was measured by BECKMAN COULTER (PHI470) of China. Soil salinity was also measured directly from the field and it ranged from 1.87 to $4.7 \mathrm{dS} \mathrm{m} \mathrm{m}^{-1}$. Seeds of BRRI dhan47 were collected from BRRI Regional Station, Barisal. Trial farmers raised quality seedlings in wet bed and 30-35 day-old seedlings were transplanted in the trial plots (Table 1).

The experimental design was a RCBD with disperse replication in 5 farmers' field under irrigated condition. Layout was done carefully maintaining unit plot size 50 square meters for each treatment. Ridges (bunds) were given for protecting unexpected irrigation water entrance into the plots or avoid contamination of water. Transplanting was done following spacing of 20 $\mathrm{cm} \times 20 \mathrm{~cm}$ at $2 / 3$ seedlings per hill. Weeds were controlled manually twice at 25-30 and 40-45 days after transplanting. All crop management operations (seedling raising, land preparation, crop establishment, irrigation, weed control, 
insect and disease control) were done by the farmers themselves in all treatments similarly. Monitoring was done through frequent field visit, keeping close contact with respective farmers, NGO field staffs and Sub-assistant Agriculture Officer (SAAO) of Department of Agriculture Extension (DAE) during the crop growing period.

Data on yield and yield components were collected from each treatment of 5 trials. A 5-hill plant sample was collected at physiological maturity stage to determine yield components. Grain yields were obtained from a central $5 \mathrm{~m}^{2}$ harvest area in each plot at maturity and were adjusted to $14 \%$ moisture content. For taking moisture data, grain moisture meter (GMK303RS), G-WON HITECH Co. LTD, Korea was used. Samples were weighed using a digital balance. Straw samples of $5 \mathrm{~m}^{2}$ were sun-dried to constant weight. Harvest index (HI) was calculated from adjusted grain weight divided by total harvest (grain weight + sun dried straw weight + unfilled spikelet's weight).

Data were analyzed using the CropStat7.2 software. Optimum N, P and K doses were calculated following equations given by Driessen (1986) as:

$$
\begin{array}{ll}
\text { i. } & N=\left[\left(Y_{N P K}-Y_{P K}\right) / N_{U}\right] \times 18 \\
\text { ii. } & P=\left[\left(Y_{N P K}-Y_{N K}\right) / P_{U}\right] \times 2.5 \\
\text { iii. } & K=\left[\left(Y_{N P K}-Y_{N P}\right) / K_{U}\right] \times 20
\end{array}
$$

Where, $Y_{N P K}=$ yield in NPK plots, $Y_{P K}=$ yield in $\mathrm{N}$ omission plot, $Y_{N K}=$ yield in $\mathrm{P}$ omission, $Y_{N P}=$ yield in $\mathrm{K}$ omission plot, $N_{U}=\mathrm{N}$ use efficiency (assuming 40\%), $P_{U}=\mathrm{P}$ use efficiency (assuming 60\%), and $K_{U}=\mathrm{K}$ use efficiency assuming 80\% (Islam et al., 2012 and BRRI, 2004).

For comparison between estimated SSNM dose and farmers practice and estimation gross return over fertilizer (GRF), yield data as well as fertilizer amounts that have been used by the farmers were collected from 4 farmers of the same area. The average (adjusted in 14\%) grain yield in farmers practice was recorded as $5.53 \mathrm{t}$ $\mathrm{ha}^{-1}$ and that of N, P, and $\mathrm{K}$ doses are provided in Table 3. TFC and GRF were calculated using the following equations:

$$
\begin{array}{ll}
\text { iv. } & T F C=P_{N} F_{N}+P_{P} F_{P}+P_{K} F_{K} \\
\text { v. } & G R F=P_{R} Y_{R}-T F C
\end{array}
$$

Where, $T F C=$ total fertilizer cost $\left(\$ \mathrm{ha}^{-1}\right), P_{N}=$ price of $\mathrm{N}$ fertilizer $\left(\$ 0.53 \mathrm{~kg}^{-1} \mathrm{~N}\right), F_{N}=$ amount of $\mathrm{N}$ applied $\left(\mathrm{kg} \mathrm{N}^{-1}\right), P_{P}=$ price of $\mathrm{P}$ fertilizer $\left(\$ 1.71 \mathrm{~kg}^{-1} \mathrm{P}\right), F_{P}=$ amount of $\mathrm{P}$ applied $(\mathrm{kg} \mathrm{P}$ $\left.\mathrm{ha}^{-1}\right), P_{K}=$ price of $\mathrm{K}$ fertilizer $\left(\$ 0.44 \mathrm{~kg}^{-1} \mathrm{~K}\right)$, $F_{K}=$ amount of $\mathrm{K}$ applied $\left(\mathrm{kg} \mathrm{K} \mathrm{ha}^{-1}\right), G R F=$ gross return over fertilizer $\left(\$ \mathrm{ha}^{-1}\right), P_{R}=$ price of rice $\left(\$ 0.17 \mathrm{~kg}^{-1}\right.$ paddy), and $Y_{R}=$ rice yield $(\mathrm{kg}$ $\left.\mathrm{ha}^{-1}\right)$.

\section{Results and Discussion}

Taller plants $(99.32 \mathrm{~cm})$ were found in NPK treatment and it varied significantly among the treatment $\mathrm{PK}(-\mathrm{N})$, where it was observed as $85.44 \mathrm{~cm}$ (Table 2).

The number of tiller $\mathrm{m}^{-2}$ varied significantly in different nutrient management treatments. The highest number of tiller $\mathrm{m}^{-2}$ (369) was observed in NPK treatment. The lowest number of tiller $\mathrm{m}^{-2}$ (249) was observed in $\mathrm{N}$ omission treatment. Similarly, the number of panicle $\mathrm{m}^{-2}$ varied significantly in different nutrient management treatments. The highest number of panicle $\mathrm{m}^{-2}$ (320) was observed in NPK treatment. The lowest number of panicle $\mathrm{m}^{-2}$ (215) was observed in $\mathrm{N}$ omission treatment.

The highest number of grain panicle ${ }^{-1}$ (78) was observed in $\mathrm{K}$ omission treatment. The grain panicle $^{-1}$ (74) of NPK treatment was statistically similar with $\mathrm{K}$ omission treatment. The lowest number of grain panicle ${ }^{-1}$ (55) was observed in $\mathrm{N}$ omission treatment. The grain panicle ${ }^{-1}$ of $\mathrm{N}$ omission and also that of $\mathrm{P}$ omission were significantly lower than that of $\mathrm{K}$ omission treatment. 
Nath et al. /The Agriculturists 11(1): 8-14 (2013)

Table 2. Effect of fertilizer treatments on plant height, number of tillers $\mathrm{m}^{-2}$ and yield components of BRRI dhan47 at Kalapara during Boro, 2012

\begin{tabular}{lccccccc}
\hline Treatment & $\begin{array}{c}\text { Plant } \\
\text { height } \\
(\mathrm{cm})\end{array}$ & $\begin{array}{c}\text { Number } \\
\text { of tiller } \\
\mathrm{m}^{-2}\end{array}$ & $\begin{array}{c}\text { Number of } \\
\text { panicle } \\
\mathrm{m}^{-2}\end{array}$ & $\begin{array}{c}\text { Number } \\
\text { of grains }_{\text {panicle }^{-1}}\end{array}$ & $\begin{array}{c}\text { Thousand } \\
\text { grain wt. } \\
(\mathrm{g})\end{array}$ & $\begin{array}{c}\text { Grain } \\
\text { yield } \\
\left(\mathrm{t} \mathrm{ha}^{-1}\right)\end{array}$ & $\begin{array}{c}\text { Harvest } \\
\text { index }\end{array}$ \\
\hline $\mathrm{NPK}$ & 99.32 & 369 & 320 & 74 & 24.75 & 5.64 & 0.53 \\
$\mathrm{PK}(-\mathrm{N})$ & 85.44 & 249 & 215 & 55 & 23.43 & 2.78 & 0.46 \\
$\mathrm{NK}(-\mathrm{P})$ & 93.32 & 283 & 252 & 69 & 20.53 & 3.70 & 0.47 \\
$\mathrm{NP}(-\mathrm{K})$ & 94.88 & 312 & 271 & 78 & 23.91 & 5.13 & 0.52 \\
$\mathrm{LSD}_{(0.05)}$ & 9.27 & 66.76 & 61.75 & 7.13 & 1.05 & 1.18 & 0.07 \\
$\mathrm{CV}$ & 7.2 & 16.0 & 16.9 & 7.5 & 21.5 & 19.8 & 11.2 \\
\hline
\end{tabular}

Table 3. N, P, K doses applied in the study plots at Kalapara during Boro 2012 season

\begin{tabular}{ccccc}
\hline Nutrient & $\begin{array}{c}\text { Amount applied } \\
\left(\mathrm{kg} \mathrm{ha}^{-1}\right)\end{array}$ & $\begin{array}{c}\text { Farmers' practice } \\
\left(\mathrm{kg} \mathrm{ha}^{-1}\right)\end{array}$ & $\begin{array}{c}\text { Amount to be } \\
\text { applied }\left(\mathrm{kg} \mathrm{ha}^{-1}\right)\end{array}$ & Amount saved (\%) \\
\hline $\mathrm{N}$ & 125.3 & 99.91 & 128.7 & - \\
$\mathrm{P}$ & 18 & 17.29 & 8.08 & 55.11 \\
$\mathrm{~K}$ & 53 & 43.57 & 12.78 & 75.89 \\
\hline
\end{tabular}

There were significant differences in case of thousand grain weight for the treatments. The highest grain weight was found in NPK treatment. The lowest grain weight was found in $\mathrm{P}$ omission plot and it was significantly lower than that of NPK, PK $(-\mathrm{N})$ and NP $(-\mathrm{K})$. The highest grain-yield $\left(5.64 \mathrm{t} \mathrm{ha}^{-1}\right)$ was observed in NPK treatment and it was varied significantly with treatments PK $(-\mathrm{N})$ and NK (-P). The lowest grain yield $\left(2.78 \mathrm{t} \mathrm{ha}^{-1}\right)$ was found in $\mathrm{N}$ omission treatment. The yield of NP (-K) was statistically similar with the treatment NPK. The highest harvest index (0.53) was observed in NPK treatment and the lowest harvest index (0.47) was observed in $\mathrm{N}$ omission treatment.

The calculated N, P \& K doze are 128.7, 8.08 \& $12.78 \mathrm{~kg} \mathrm{ha}^{-1}$. So, P and $\mathrm{K}$ will be saved by 55.11 and $75.89 \%$, respectively (Table 3 ).

Using equation $i v$, it was found that total fertilizer cost (TFC) for applied doses was $120.51 \$ \mathrm{ha}^{-1}$ and the TFC that would be applied according to $(i)$, (ii), and (iii) was $87.86 \$ \mathrm{ha}^{-1}$.
So, total savings was $32.86 \$ \mathrm{ha}^{-1}$. It was also found from Table 3 that TFC of farmers practice is $101.69 \$ \mathrm{ha}^{-1}$. Using equation $v$ it can be calculated that SSNM doses led to an increase in GRF by $23.92 \$$ ha $^{-1} \mathrm{crop}^{-1}$ compared to farmer's fertilizer practice.

The NPK treatment gave 9.0, 34.4 and $50.7 \%$ higher yields than NP, NK and PK treatments, respectively. The highest grain-yield was observed in NPK treatment (5.64 $\left.\mathrm{t} \mathrm{ha}^{-1}\right)$, which is attributed to higher number of tillers as well as panicles per unit area, higher number of grains per panicle, highest thousand grain-weight and higher harvest index compared to that of NP, NK and PK treatments.

The treatment PK (N omission) produced the lowest grain-yield and it was significantly lower than that of NPK and NP. It was due to the lowest number of tillers as well as panicles per square meter and lowest number of grains per panicle. Harvest index in PK treatment was also significantly lower than in NPK treatment. The 
response of indigenous $\mathrm{N}$ was very poor for rice production in the locality. This may be due to the low organic matter content of the soil (1-1.5\%). Similar organic matter percentage in the coastal soil of Bangladesh was reported by Haque (2006). The treatment NK (P omission) produced lower grain yield than NPK and NP treatments. The yield was lower in NK plot perhaps due to lower number of tillers as well as lower number of panicles per square meter and the lowest thousand grain-weight. This is may be due to low availability of $\mathrm{P}$ in the soil. According to Fertilizer Recommendation Guide (BARC, 2005) for the Gangetic Tidal Floodplain soil (AEZ 13), P status ranges from very low to low levels.

The treatment NP ( $\mathrm{K}$ omission) produced the second highest yield and it was also significantly higher than in $\mathrm{N}$ omission treatment. It may also be due to the higher number of tillers as well as panicles per square meter and also thousand grain-weight. Thus, the yield response to indigenous $\mathrm{K}$ was remarkable. This may be due to having high mineral, non-exchangeable and available $\mathrm{K}$ and high release potential of the soil. Similar result was reported by Moslehuddin and Egashira (1999) for AEZ 13.

The calculated N, P \& K dozes were 128.7, 8.08 and $12.78 \mathrm{~kg} \mathrm{ha}^{-1}$. However, calculated $\mathrm{N}$ doze is little bit higher than BRRI recommended doze. $\mathrm{P}$ and $\mathrm{K}$ doze are much lower than the recommended dozes and would be saved by 55.11 and $75.89 \%$, respectively. Farmer's doses of $\mathrm{P}$ and $\mathrm{K}$ were also high compared to calculated dose. Calculated fertilizer doses may lead to an increase in GRF compared to farmer's fertilizer practice. Similar result was observed by Khurana et al. (2007). Moreover, the environmental benefits that could be generated by SSNM in long-term and which have not been accounted for in these calculations, might help in further increasing the profitability of this SSNM approach, e.g., farmers may get environmental credit under the Kyoto Protocol (Khurana et al., 2007).

\section{Conclusions}

Depending on the response of soil indigenous nutrient elements ( N, P and $\mathrm{K}$ ) it may be concluded that nitrogen and phosphorus are the most limiting factors to increase grain-yield in Nilganj union of Kalapara upazila, Patuakhali while $\mathrm{K}$ omission have no significant impact on grain yield. To produce rice (yield target $6 \pm 0.6 \mathrm{t}$ $\mathrm{ha}^{-1}$ ) in Boro season farmers may apply N, P and $\mathrm{K}$ at $128.7,8.08$ and $12.78 \mathrm{~kg}$, respectively. It can save $\mathrm{P}$ and $\mathrm{K}$ nutrient by 55.11 and $75.89 \%$, respectively compared to recommended doze. Further study is needed to compare between Farmers' practice and SSNM recommended doses in the same farmers' field in order to evaluate the approach and to evaluate the yield as well as gross return over fertilizer (GRF). A simplified SSNM approach is necessary with similar socio-economic and biophysical conditions.

\section{Acknowledgment}

The research was supported by USAID funded Cereal Systems Initiative for South Asia (CSISA) project in Bangladesh under International Rice Research Institute (IRRI). We acknowledge the contributions made by other scientists of IRRI and BRRI involved in this research with data management and statistical analysis. We are grateful to the farmers of Nilganj, Patuakhali for their patience and excellent cooperation in conducting the on-farm experiments.

\section{References}

Amina Khatun and Saleque M. A. 2010. Farmers' Participatory Field Specific Nutrient Management in Tidal Flooded Soil for HYV Aus Rice 2010. The Bangladesh J. of Scientific Res., 23:7380 .
BARC (Bangladesh Agricultural Research Council) 2005. Fertilizer Recommendation Guide-2005. Soil


publications, November 30, 2005, 45: 23, 60-62.

Betteridge K., Schnug E. and Haneklaus S. 2008. Will site specific nutrient management live up to expectation? Agriculture and Forestry Research, 4(58): 283-294.

BRRI (Bangladesh Rice Research Institute) 2004. Bangladesh Rice Research Institute internal review report for 2003-2004, Soil science Division.

BRRI (Bangladesh Rice Research Institute) 2011. Adhunik Dhaner Chash. $16^{\text {th }}$ edition, 70-72 p.

Cassman K. G., Dobermann A., Cruz P. C. S., Gines H. C., Samson M. I., Descalosta J. P., Alcantra J. M., Dizon M. A. and Olk D. C. 1999. Soil organic matter and the indigenous nitrogen supply of intensive irrigated rice systems in the tropics. Plant Soil, 182: 267-278.

Chowdhury T., Ayam G. P., Gupta S. B., Das G. K. and Pradhan M. K. 2007. Internal nutrient supply capacity of vertisols for rice in Chhattisgarh agro-climatic conditions of India. Bangladesh J. Agril Res., 32: 501-507.

Driessen P. M. 1986. Nutrient demand and fertilizer requirements. In Keulen H. Van and Wolf J. (eds.). Modeling of agricultural production: weather, soils and crops. Pudoc, Wageningen, The Netherland, 182-202 p.

Haque S. A. 2006. Salinity problems and crop production in coastal regions of Bangladesh. Review Article. Pak. J. Bot., 38(5): 1359-1365

Islam M. Sh., Rahman F., Moniruzzaman M., Mahmud N. H. and Saleque M. A. 2012, Farmers' Participatory Site Specific Nutrient Management in Tidal Flooded Soil for High Yielding Aus Rice. Submitted to Bangladesh Rice Journal. Vol. 16.
Khosla R., Fleming K., Delagado J. A., Shaver T. M. and Westfall D. G. 2002. Use of site-specific management zones to improve nitrogen management for precision agriculture. J. Soil Water Conserv., 57: 513-518.

Khurana H. S., Phillips S. B., Bijay-Singh, Dobermann A., Sidhu A.S., Yadvinder Singh and Shaobing Peng 2007. Performance of Site-Specific Nutrient Management for Irrigated, Transplanted Rice in Northwest India. Agronomy J., 99:1436-1447.

Maniruzzaman M., Biswas J. C., Kabir M. S., Saleque M. A. and Sattar M. A. 2008. Soil fertility mapping at micro level for rice production: Prashadkalua village. Bangladesh Rice J., 13:23-29.

Moslehuddin A.Z.M. and Egashira K. 1999. Potassium chemistry in some important paddy soils of Bangladesh. Communications in Soil Science and Plant Analysis (USA), ISSN 0010-3624, 30(3-4):329-344

Saleque M. A., Rashid H., Van Mile P., and Bentley J. W. 2005. Village soil fertility maps, In: P. Van Mile, A. Salahuddin, and N. P. Magor (eds.). Innovations in rural extension: Case studies from Bangladesh. CABI Publishing, Wallingford, U.K., 89$102 \mathrm{p}$.

Saleque M. A., Uddin M. K., Ferdous A. K. M and Rashid M. H. 2008. Use of farmers' empirical knowledge to delineate soil fertility-management zones and improved nutrient-management for lowland rice. Commu. Soil Sci. Plant Anal, 39:25-45.

Swanson E. R. 1982. Economic implications of controls on nitrogen fertilizer use. In F. J. Stephenson (ed.) Nitrogen in agricultural soils. Agron. Monogr. 22. ASA and SSSA, Madison, WI., 773-790 p. 